УДК $630 * 182.21(571.53)$

ПЕРСПЕКТИВНЫЕ ВИДЫ И ФОРМЫ ХВОЙНЫХ ЭКЗОТОВ ДЛЯ ОЗЕЛЕНЕНИЯ НАСЕЛЕННЫХ ПУНКТОВ СЕВЕРНЫХ ТЕРРИТОРИЙ ИРКУТСКОЙ ОБЛАСТИ

\author{
${ }^{1}$ Гнаткович П.С., ${ }^{2}$ Рунова Е.М. \\ ${ }^{1}$ Филиал ФГБОУ ВО «Байкальский государственньй университет», \\ Усть-Илимск, е-mail: uigea@irtel.ru; \\ ${ }^{2}$ ФБОУ ВО «Братский государственный университет», Братск, е-таil: rector@brstu.ru
}

\begin{abstract}
В статье рассмотрены вопросы расширения видового ассортимента зеленых насаждений населенных пунктов северных территорий Иркутской области за счет внедрения новых видов, форм и культиваров хвойных интродуцентов (на примере северной столицы региона - города Братска). Проанализированы имеющиеся проблемы введения в культуру интродуцированных деревьев и кустарников. В статье приводятся результаты многолетних интродукционных испытаний хвойных инорайонных видов, произрастающих в городе Братске (исследования проводятся с 2008 г. по настоящее время). Даны оценки морозоустойчивости, засухоустойчивости, дымо- и газоустойчивости хвойных растений. Приводятся сведения по ежегодному приросту растений, морфометрические показатели экзотов и степень адаптации в природно-климатических условиях Братска и его окрестностей. Для определения перспективности использования хвойных интродуцентов в озеленении населенных пунктов проведена комплексная оценка успешности интродукции по методике Главного ботанического сада, используя следующие критерии: степень вызревания побегов, зимостойкость, сохранение габитуса, побегообразование, регулярность прироста побегов, способность к генеративному развитию и способы размножения, характеризующие состояние и перспективы выращивания растений в городских условиях. Даны рекомендации по использованию хвойных деревьев и кустарников в городском озеленении для повышения устойчивости, долговечности зеленых насаждений, а также улучшению эстетических свойств городских посадок и обогащения визуальной среды. Всего в статье описано 27 видов, подвидов и декоративных форм хвойных экзотов, которые успешно адаптировались в природно-климатических условиях северных районов Иркутской области. Данные виды и культивары можно рекомендовать к использованию в разных формах городского озеленения и частном садоводстве на дачных и приусадебных участках.
\end{abstract}

Ключевые слова: хвойные растения, экзоты, интродукция, акклиматизация, ассортимент растений, зимостойкость, озеленение, Братск

\title{
PROSPECTIVE SPECIES AND FORMS OF CONIFEROUS EXOTOES FOR LANDSCAPING IN POPULATIONS IN THE NORTHERN TERRITORIES OF THE IRKUTSK REGION
}

\author{
${ }^{1}$ Gnatkovich P.S., ${ }^{2}$ Runova E.M. \\ ${ }^{1}$ Baykal State University, branch, Ust-Ilimsk, e-mail: uigea@irtel.ru; \\ ${ }^{2}$ Bratsk State University, Bratsk, e-mail: rector@brstu.ru
}

\begin{abstract}
The article discusses the issues of expanding the species range of green spaces in settlements in the northern territories of the Irkutsk region through the introduction of new species, forms and cultivars of coniferous introduced species (for example, the northern capital of the region - the city of Bratsk). The existing problems of introducing introduced trees and shrubs into the culture are analyzed. The article presents the results of long-term introduction tests of coniferous foreign species growing in the city of Bratsk (studies have been carried out since 2008 to the present). Estimates of frost resistance, drought resistance, smoke and gas resistance of conifers are given. Information on the annual growth of plants, morphometric indicators of exotic species and the degree of adaptation in the natural and climatic conditions of Bratsk and its environs are given. To determine the prospects for the use of coniferous introduced species in the landscaping of settlements, a comprehensive assessment of the success of the introduction was carried out according to the methodology of the Main Botanical Garden, using the following criteria: the degree of ripeness of the shoots, winter hardiness, preservation of habitus, shoot formation, the regularity of shoot growth, the ability for generative development and the methods of reproduction that characterize the state and the prospects for growing plants in an urban setting. Recommendations are given on the use of coniferous trees and shrubs in urban landscaping to increase the sustainability, durability of green spaces, as well as improve the aesthetic properties of urban plantings and enrich the visual environment. In total, the article describes 27 species, subspecies and decorative forms of coniferous exotic plants, which have successfully adapted to the natural and climatic conditions of the northern regions of the Irkutsk region. These species and cultivars can be recommended for use in various forms of urban landscaping and private gardening in summer cottages and household plots.
\end{abstract}

Keywords: conifers, exotic plants, introduction, acclimatization, assortment of plants, winter hardiness, landscaping, Bratsk

Интродукция древесных пород играет большую роль в обогащении видового ассортимента городских насаждений и увеличении биоразнообразия в районах с бедным флористическом составом, к кото- рым, безусловно, относится Иркутская область и другие регионы Восточной Сибири. В этих регионах наблюдаются достаточно суровые природно-климатические условия, в которых полноценно функционировать 
может ограниченное количество древесных растений. Аборигенная дендрофлора северных районов Иркутской области насчитывает 44 вида древесно-кустарниковых растений, из которых хвойных всего 6 видов: ель сибирская (Picea obovata Ledeb.), лиственница сибирская (Larix sibirica Ledeb.), можжевельник обыкновенный (Juniperus communis L.), пихта сибирская (Abies sibirica Ledeb.), сосна обыкновенная (Pinus sylvestris L.), сосна сибирская кедровая (P. sibirica DuTour) $[1,2]$.

Тем временем хвойные открывают широкие возможности для улучшения архитектурно-художественного облика сибирских городов, обладая высокой декоративностью в течение всего года. При этом перечень хвойных пород, который предлагают местные питомники, очень беден. Декоративные формы и культивары вообще не используются. Поэтому возникает острая необходимость интродукционных испытаний новых видов и декоративных форм, с последующей рекомендацией их к использованию в зеленом строительстве и частном садоводстве.

Главными факторами выживания древесных растений в открытом грунте и акклиматизации в целом на территориях с резко континентальным климатом является температура воздуха и почвы в зимне-весенний период и продолжительность сильных морозов [3]. При этом на выживание растений оказывает влияние и ряд микроклиматических факторов: высота местности над уровнем моря, экспозиция склонов, наличие строений, влияния водоемов, интенсивность и направление ветров, влияние городских условий и т.д. [4].

Таким образом, для интродукционных испытаний необходимо использовать виды и культивары, происходящие из схожих природно-климатических районов, а при изучении адаптации к новым условиям произрастания обязательно учитывать микроклиматические различия. Широкие возможности для интродукционных испытаний в северных районах Иркутской области открывают североамериканские, дальневосточные виды, а также некоторые выходцы из северных районов Европы и Центральной Азии [5-7].

Актуальность исследования подтверждается тем, что для городов и поселков северных территорий Иркутской области интродукционные испытания практически не проводились. Обобщающих работ и специальных флористических исследований по изучению интродуцентов крайне мало.
Цель исследования - оценить перспективность новых видов, форм и культиваров хвойных интродуцентов для зеленого строительства и частного садоводства северных районов Иркутской области.

\section{Материалы и методы исследования}

Как правило, испытания акклиматизации и адаптации древесных экзотов проводятся в местных интродукционных центрах - apборетумах, дендрариях, ботанических садах и т.д., где проводятся многолетние наблюдения за растениями и дается оценка их перспективности. Но в северных районах Иркутской области таких центров нет, и город Братск не исключение. Поэтому нами был найден альтернативный подход к изучению перспективности древесных экзотов. В условиях, где нет специализированных учреждений, занимающихся интродукционными испытаниями, частные сады жителей городов и поселков могут служить научной площадкой по испытанию инорайонных видов, обладающих исключительными эстетическими качествами [8]. Местные садоводы охотно поддерживают любительскую селекцию, акклиматизацию, интродукцию древесных растений. Некоторые исследователи недооценивают роль частных садов и питомников в интродукционных испытаниях. Но наши наблюдения доказывают обратное - частные коллекции могут способствовать обогащению дендрофлоры региона.

Таким образом, объектами исследования являются декоративные виды, разновидности и культивары хвойных растений, произрастающих в природно-климатических условиях г. Братска и его окрестностей.

Оценка морозоустойчивости и перспективности хвойных растений оценивалась по методике Главного ботанического сада [9], несколько модифицированной А.В. Гусевым с соавт. [10]. Оценка морфометрических показателей производилась с помощью общепринятой методики: измерялись высота растения, толщина ствола, ширина кроны, высота ствола до кроны. Исследования хвойных экзотов проводились в течение длительного времени (начиная с 2008 г.), чтобы в этот период попали годы с разной метеорологической ситуацией, а полученные результаты были полными и объективными. Все данные заносились в специальные дневники наблюдений, и в последующем систематизировались, обобщались и анализировались. В общем, за время многолетних исследований было изучено более 1500 экземпляров хвойных 
экзотов, относящихся к разным семействам, родам, видам, сортам и декоративным формам.

\section{Результаты исследования и их обсуждение}

Ель сизая, или канадская (Picea glauca (Moench) Voss.) - дерево родом из северных районов Северной Америки. В Условиях Братска успешно произрастают три селекционные формы, обладающие высочайшими декоративными качествами: «Коника», «Дейзис Уайт» и «Перфекта». Ель сизая «Коника» (P. glauca «Conica») - морозостойкий, но медленнорастущий сорт. Отлично зимует в условиях Братского района, но в год наращивает не более 1-2 см прироста, в возрасте 10 лет высота составляет всего около $50 \mathrm{~cm}$. Нуждается в защите от яркого весеннего солнца, так как может обгорать. Рекомендуется использовать при одиночных посадках, в группах, альпинариях. Ель сизая «Дейзис Уайт» (P. glauca «Daisy's White») - в год в условиях Братска наращивает так же, как и «Коника», около 1-2 см прироста, в 10-летнем возрасте достигает не более 40 см высоты. Отлично зимует, но может выгорать от весеннего солнца, поэтому так же, как и другие канадские ели, нуждается в весеннем притенении. Рекомендуется сажать в качестве солитера на газоны, в роли декоративного элемента на альпийских горках. Ель сизая «Перфекта» (P. glauca «Perfecta») отлично зимует, к 10 годам в Братске вырастает до 1,0 М. Годовой прирост в среднем 2-3 см. Страдает от весенних ожогов, на открытом солнце хвоя обгорает - необходимо притенение. Рекомендуется использовать как солитер или в группе.

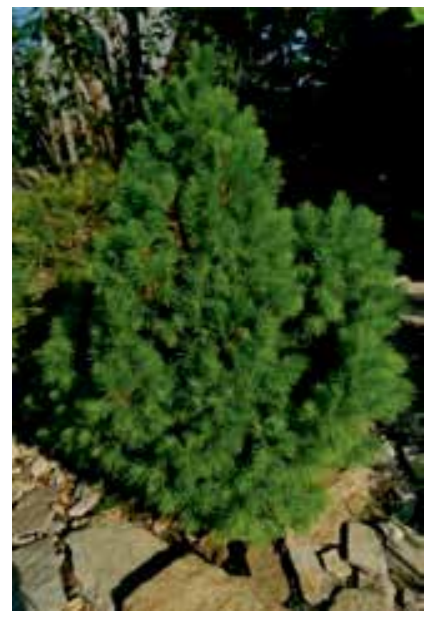

Puc. 1. Picea glauca «Conica» в озеленении частного сада (возраст 8 лет) (фото автора)
Ель колючая, или голубая (P. pungens Engelm.) - дерево родом из Северной Америки. В Братске встречаются три декоративные формы: «Глаука», «Глаука Глобоза» и «Белобок». Ель колючая «Глаука» (P. pungens «Glauca») - дерево с приростом в условиях Братска - не более 5 см в год. В возрасте 12 лет достигает в высоту 1,7 м. Рекомендуется для выращивания в одиночных посадках, в парках, групповых композициях у парадных зданий. Ель колючая «Глаука Глобоза» (P. pungens «Glauca Globosa») - карликовый культивар. Морозоустойчива, засухоустойчива и газоустойчива. В Братске ежегодный прирост 3-4 см в год. В 8-летнем возрасте - 38 см высотой. Рекомендуется для одиночных и групповых посадок на газоне и на альпинариях. Ель колючая «Белобок» (P. pungens «Bialobok») в Братске достигает 1,5 м в высоту и 0,8 м в диаметре в 15 лет. Отлично зимует. Рекомендуется для одиночных посадок и групп, озеленения террас.

Ель обыкновенная, или европейская (P. abies L.) - дерево родом из Европы. На территории Братска и окрестностей встречаются два популярных сорта ели обыкновенной: «Акрокона» и «Нидиформис». Ель обыкновенная «Акрокона» (P. abies «Acrocona») - в Братске к 15 годам достигает высоты 2 м и диаметра кроны 1,2 м. Годовой прирост в высоту 4-5 см. Рекомендуется использовать для одиночных посадок и в качестве акцента в малых садах, в группах, для создания рокариев. Ель обыкновенная «Нидиформис» (P. abies «Nidiformis») - в природно-климатических условиях Братска прирост в год до 5 см в ширину и до 3 см в высоту. К 10 годам достигает высоты около 0,8 м и в диаметре до 1 м. Зимует отлично. Рекомендуется для размещения в групповых посадках, одиночных посадках, каменистых садах.

Ель Сербская (P. omorica (Panc.) Purk) - эндемик Западной Сербии и Восточной Боснии и Герцеговины. Годовой прирост в высоту в условиях Братска - 10$12 \mathrm{~cm}$, в 15-летнем возрасте достигает 2,4 м. Рекомендуется для посадок на аллеях, одиночных посадках, живой изгороди.

Пихта одноцветная (Abies concolor (Gordon) Lindl. ex Hildebr.) - дерево семейства сосновых, родом из горных высот Северной Америки. В Братске встречаются два сорта этого вида: «Виолацеа» и «Винтер Голд». Пихта одноцветная «Виолацеа» (A. concolor «Violacea») в природно-климатических условиях Братска в 12-летнем 
возрасте достигает 1,1 м. Рекомендуется использовать в групповых композициях и одиночных посадках. Пихта одноцветная «Винтер Голд» (A. concolor «Winter Gold») в Братске высота достигает 1 м в 10-летнем возрасте. Рекомендуется в качестве солитеров и для создания аллей.

Сосна горная, или стланиковая европейская (Pinus mugo Turra) - хвойный кустарник (реже дерево) из семейства сосновых, родом из Центральной и Южной Европы. В Братске выращивают две природные разновидности сосны горной - Мугус (P. mughus) и Пумилио (P. pumilio). Сосна горная Мугус (P. mugo var.mughus (Scop.) Zenari) - зимостойка, дымо- и газоустойчива. Отлично зимует. В условиях Братска 1 м в высоту достигает к 13-летнему возрасту. Рекомендуется для альпинариев, озеленения склонов, оврагов. Сосна горная Пумилио (P. mugo var. Pumilio (Haenke) Zenari) прекрасно зимует в Братске. Дымо- и газоустойчива. В условиях Братска 1 м в высоту достигает к 15-летнему возрасту. Рекомендуется для посадки группами или одиночно на газоне. Хорошо переносит стрижку.

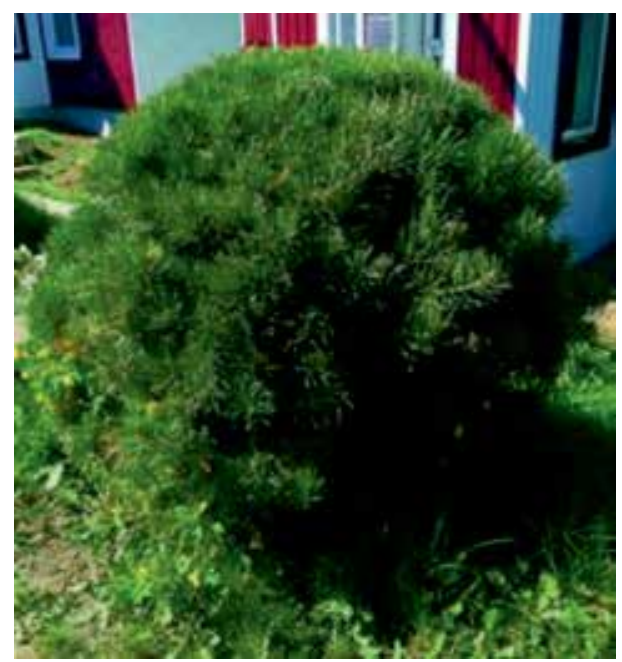

Puc. 2. Pinus mugo var. Pumilio в городском озеленении (возраст 10 лет)

Можжевельник горизонтальный (Juniperus horizontalis Moench) - кустарник семейства кипарисовых родом из Северной Америки. Данный вид хорошо переносит весеннее солнце и не нуждается в укрытии весной в отличие от других представителей рода. В Братске чаще всего используют два сорта - «Блю Чип» и «Принц Уэльский». Можжевельник горизонтальный «Блю Чип» (J.horizontalis «Blue Chip») очень хорошо зимует в Братске, в возрасте 14 лет достигает 30 см высоты и до 1,6 м диаметра кроны. Рекомендуется использовать в одиночных и групповых посадках на каменистых горках, на склонах и откосах. Можжевельник горизонтальный «Принц Уэльский» (J. horizontalis «Prince of Wales») отлично зимует в условиях Братска, к 10-летнему возрасту достигает 15 см в высоту и более 2 м в диаметре. Рекомендуется применять на каменистых горках или как почвопокровное растение.

Можжевельник казацкий (J. sabina L.) стелющийся кустарник с обширным ареалом обитания на всем северном полушарии. В Братске успешно произрастают две декоративные формы - «Глаука» и «Тамарисцифолия». Можжевельник казацкий «Глаука» (J. sabina «Glauca») в Братске к 12 годам высота 0,8 м и диаметр кроны 3,8 м. Засухоустойчив, мало поражается болезнями и вредителями. Отлично зимует, пыле-, дымо- и газоустойчив, не подвержен ранневесенним ожогам, что делает его идеальным хвойным кустарником для городских насаждений. Рекомендуется для городских условий, для больших пейзажных садов и в качестве почвопокровного растения. Можжевельник казацкий «Тамарисцифолия» (J. sabina «Tamariscifolia») - невысокая медленнорастущая форма можжевельника казацкого, отлично зимует в Братске. Так же как и сорт «Глаука», нетребователен в уходе, мало повреждается болезнями и устойчив к весеннему солнцу. В условиях Братска годовой прирост до 5 см. В 12-летнем возрасте достигает 30 см высоты и около 1,4 м диаметра. Рекомендуется применять в разных формах городского зеленого строительства.

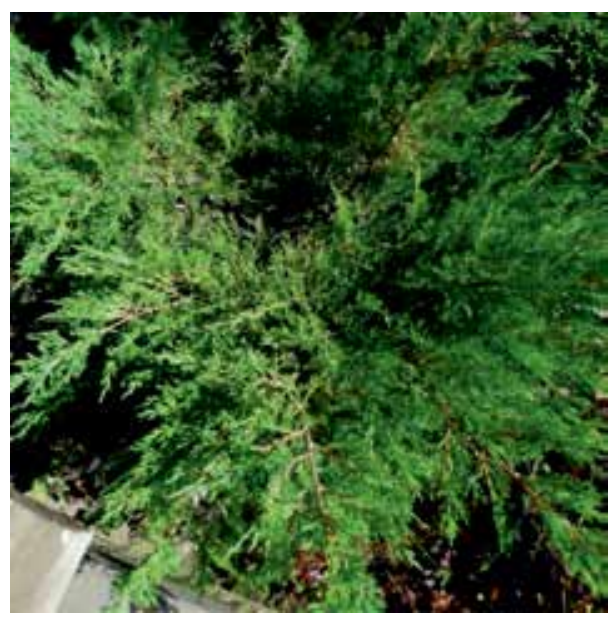

Puc. 3. Juniperus sabina «Glauca» в озеленении частного сада (возраст 10 лет) 


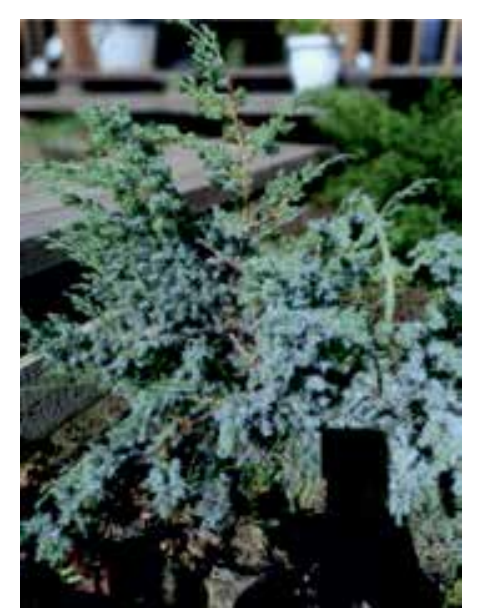

Puc. 4. Juniperus chinensis «Blue Alps» в озеленении частного сада (возраст 7 лет)

Можжевельник чешуйчатый (J. squamata Lamb.) - стелющийся кустарник, родом из Центральной Азии. В Братске чаще всего встречаются два сорта этого растения: «Блю Карпет» и «Блю Швед». Можжевельник чешуйчатый «Блю Карпет» (J. squamata «Blue Carpet») прекрасно зимует, но страдает от ранневесенних ожогов. В условиях Братска достигает в 12-летнем возрасте 30 см высоты и более 1 м диаметра кроны. Рекомендуется для использования в одиночных и групповых посадках, в рокариях и альпинариях, в качестве почвопокровного растения. Можжевельник чешуйчатый «Блю Швед» (J. squamata «Blue Swede») в 13-летнем возрасте в условиях г. Братска достигает высоты 0,8 м и диаметра кроны более 1,3 м. Морозостоек. Отлично зимует в Братске. Хорошо переносит городские условия. Рекомендуется для каменистых и альпийских композиций.

Можжевельник виргинский «Блю Клоуд» (J. virginiana «Blue Cloud») - кустарник, родом из Северной Америки. В условиях Братска наблюдается умеренный рост, в 12-летнем возрасте достигает в высоту 0,4 м, в ширину разрастается до $1 \mathrm{~m}$. Прекрасно зимует в Братске. Рекомендуется высаживать на каменистых горках, рокариях, террасах.

Можжевельник обыкновенный «Грин Карпет» (J. communis «Green Carpet») в г. Братске в возрасте 10 лет достигает всего 10 см высоты при диаметре 1,5 м. Отлично зимует. Рекомендуется применять для создания каменистых садов, альпийских горок и как почвопокровное растение.

Можжевельник средний «Пфитцериана» (J. media «Pfitzeriana») отлично зи-

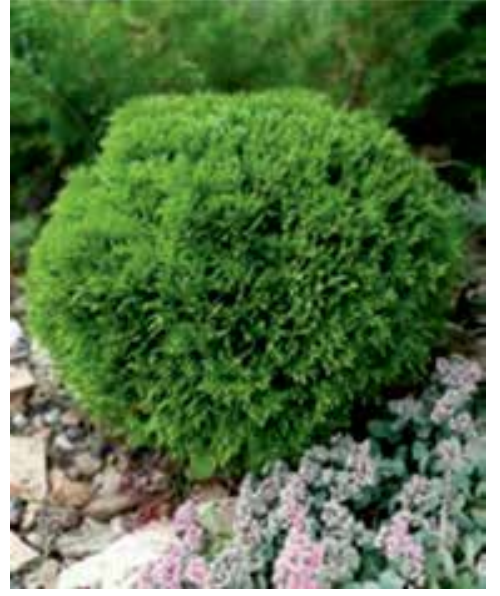

Puc. 5. Thuja occidentalis «Danica» в озеленении частного сада (возраст 8 лет)

мует в Братске, к 10 годам достигает 0,7 м высоты и около 1,5 м в диаметре. Может незначительно подгорать на весеннем солнце. Устойчив к городским условиям. Рекомендуется для посадки в композициях, рокариях и других типах насаждений.

Можжевельник китайский «Блю Альпс» (J. chinensis «Blue Alps») хорошо зимует в Братске, но сильно обгорает весной. Хорошо отзывается на обрезку. В 12-летнем возрасте достигает до 0,9 м высоты. Рекомендуется для каменистых, вересковых садов, одиночных и групповых посадок.

Туя западная (Thuja occidentalis L.) дерево бореальных хвойных лесов северо-западной части Северной Америки семейства Кипарисовых. В Братске на протяжении многих лет выращивают разные сорта туи западной. Наиболее распространённые из них: «Брабант», «Смарагд», «Холмструп», «Даника». Туя западная «Брабант» (T. occidentalis «Brabant») - в условиях Братска ежегодный прирост в высоту 12 см, в ширину -7 см. В возрасте 11 лет достигает 1,7 м. Рекомендуется для широкого использования на приусадебных участках, территориях у крупных коммерческих объектов и зон отдыха. Туя западная «Смарагд» (T. occidentalis «Smaragd») - в условиях Братска прирост в год не более 5 см в высоту, 10-летние экземпляры едва достигают 1,5 м. Рекомендуется для создания аллей, одиночных посадок и декоративных композиций. Туя западная «Холмструп» (T. occidentalis «Holmstrup») - годовой прирост в условиях Братска не более 4 см в высоту. В возрасте 10 лет достигает 0,8 м в высоту. Рекомендуется в качестве оди- 
ночных посадок, для декоративных групп, живых изгородей, аллей. Туя западная «Даника» (T. occidentalis «Danica») растет медленно, в Братске в год по 2-3 см в высоту и ширину. Высота 10-летнего растения около 40 см и столько же в диаметре. Отлично зимует в Братске, практически не повреждается весенним солнцем. Рекомендуется использовать в одиночных и групповых посадках для создания низких бордюров.

Обобщенные результаты интродукционных испытаний хвойных экзотов в условиях г. Братска приведены в таблице.

Оценка перспективности хвойных экзотов в условиях г. Братска

\begin{tabular}{|c|c|c|c|c|c|c|c|c|c|c|}
\hline \multirow[b]{2}{*}{$\begin{array}{c}\text { № } \\
\Pi / \Pi\end{array}$} & \multirow[b]{2}{*}{$\begin{array}{l}\text { Вид, } \\
\text { форма, } \\
\text { сорт }\end{array}$} & \multicolumn{4}{|c|}{$\begin{array}{c}\text { Биоэкологические } \\
\text { показатели }\end{array}$} & \multicolumn{3}{|c|}{$\begin{array}{c}\text { Биометрические показатели } \\
\text { в условиях Братска }\end{array}$} & \multicolumn{2}{|c|}{ Перспективность } \\
\hline & & 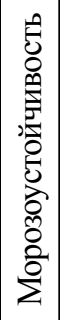 & 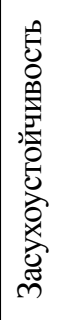 & 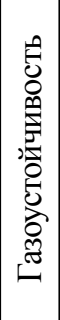 & 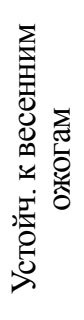 & 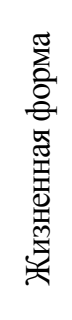 & $\begin{array}{c}\text { Высота }(H), \\
\text { диаметр } \\
\text { кроны }(D) \\
(\mathrm{m})\end{array}$ & $\begin{array}{c}\text { Годовой } \\
\text { прирост } \\
\text { (см) }\end{array}$ & 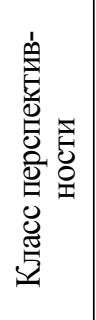 & $\begin{array}{l}\text { Применение } \\
\text { в озеленении }\end{array}$ \\
\hline 1 & 2 & 3 & 4 & 5 & 6 & 7 & 8 & 9 & 10 & 11 \\
\hline 1 & Abies concolor «Violacea» & 1 & 1 & 1 & 1 & Д & $\begin{array}{c}\text { В } 12 \text { лет: } \\
H-1,1\end{array}$ & $3-4$ & $\mathrm{C \Pi}$ & $\begin{array}{c}\text { общего } \\
\text { пользования }\end{array}$ \\
\hline 2 & A. concolor «Winter Gold» & 1 & 2 & 2 & 1 & Д & $\begin{array}{c}\text { В } 10 \text { лет: } \\
H-1\end{array}$ & $5-6$ & $\Pi$ & $\begin{array}{c}\text { ограниченного } \\
\text { пользования } \\
\end{array}$ \\
\hline 3 & $\begin{array}{l}\text { Juniperus communis } \\
\text { «Green Carpet» }\end{array}$ & 1 & 1 & 1 & 1 & $\mathrm{KC}$ & $\begin{array}{c}\text { В } 10 \text { лет: } \\
H-0,1 \\
D-1,5\end{array}$ & $2-4$ & $\mathrm{C \Pi}$ & $\begin{array}{c}\text { общего } \\
\text { пользования }\end{array}$ \\
\hline 4 & $\begin{array}{l}\text { J. horizontalis «Blue } \\
\text { Chip» }\end{array}$ & 1 & 1 & 1 & 1 & $\mathrm{KC}$ & $\begin{array}{c}\text { В } 14 \text { лет: } \\
H-0,3 \\
D-1,6\end{array}$ & $2-3$ & $\mathrm{C} \Pi$ & $\begin{array}{c}\text { общего } \\
\text { пользования }\end{array}$ \\
\hline 5 & $\begin{array}{l}\text { J. horizontalis «Prince of } \\
\text { Wales» }\end{array}$ & 1 & 1 & 2 & 1 & $\mathrm{KC}$ & $\begin{array}{c}\text { В } 10 \text { лет: } \\
H-0,15 \\
D-2\end{array}$ & $2-3$ & $\Pi$ & $\begin{array}{c}\text { ограниченного } \\
\text { пользования }\end{array}$ \\
\hline 6 & J. media «Pfitzeriana» & 1 & 1 & 1 & 2 & KP & $\begin{array}{c}\text { В } 10 \text { лет: } \\
H-0,7 \\
D-1,5\end{array}$ & $6-8$ & $\Pi$ & $\begin{array}{c}\text { ограниченного } \\
\text { пользования }\end{array}$ \\
\hline 7 & J. sabina «Giauca $»$ & 1 & 1 & 1 & 1 & KP & $\begin{array}{c}\text { В } 12 \text { лет: } \\
H-0,8 \\
D-3,8\end{array}$ & $7-8$ & $\mathrm{C} \Pi$ & $\begin{array}{c}\text { общего } \\
\text { пользования }\end{array}$ \\
\hline 8 & J. sabina «Tamariscifolia» & 1 & 1 & 1 & 1 & KP & $\begin{array}{c}\text { В } 12 \text { лет: } \\
H-0,3 \\
D-1,4\end{array}$ & $4-5$ & $\mathrm{C \Pi}$ & $\begin{array}{c}\text { общего } \\
\text { пользования }\end{array}$ \\
\hline 9 & $\begin{array}{l}\text { J. squamata } « \text { Blue } \\
\text { Carpet» }\end{array}$ & 1 & 1 & 1 & 2 & $\mathrm{KC}$ & $\begin{array}{c}\text { В } 12 \text { лет: } \\
H-0,3 \\
D-1\end{array}$ & $2-3$ & $\Pi$ & $\begin{array}{c}\text { ограниченного } \\
\text { пользования }\end{array}$ \\
\hline 10 & J. squamata «Blue Swede» & 1 & 1 & 1 & 2 & KP & $\begin{array}{c}\text { В } 13 \text { лет: } \\
H-0,8 \\
D-1,3\end{array}$ & $4-5$ & $\Pi$ & $\begin{array}{c}\text { ограниченного } \\
\text { пользования }\end{array}$ \\
\hline 11 & J. virginiana «Blue Cloud» & 1 & 1 & 1 & 2 & KP & $\begin{array}{c}\text { В } 12 \text { лет: } \\
H-0,4 \\
D-1\end{array}$ & $3-5$ & $\Pi$ & $\begin{array}{c}\text { ограниченного } \\
\text { пользования }\end{array}$ \\
\hline 12 & J. chinensis «Blue Alps» & 1 & 2 & 2 & 3 & КП & $\begin{array}{c}\text { В } 12 \text { лет: } \\
H-0,9 \\
D-0,7 \\
\end{array}$ & $8-10$ & МНП & частные сады \\
\hline 13 & Picea abies «Acrocona» & 2 & 1 & 3 & 1 & Д & $\begin{array}{c}\text { В } 15 \text { лет: } \\
H-2 \\
D-1,2\end{array}$ & $4-5$ & МНП & частные сады \\
\hline 14 & P. abies «Nidiformis» & 1 & 2 & 1 & 1 & ДК & $\begin{array}{c}\text { В } 10 \text { лет: } \\
H-0,8 \\
D-1\end{array}$ & 3 & $\Pi$ & $\begin{array}{c}\text { ограниченного } \\
\text { пользования }\end{array}$ \\
\hline
\end{tabular}




\begin{tabular}{|c|c|c|c|c|c|c|c|c|c|c|}
\hline \multicolumn{11}{|c|}{ Окончание таблицы } \\
\hline 1 & 2 & 3 & 4 & 5 & 6 & 7 & 8 & 9 & 10 & 11 \\
\hline 15 & P. glauca «Conica» & 1 & 1 & 2 & 2 & ДК & $\begin{array}{c}\text { В } 10 \text { лет: } \\
H-0,5 \\
D-0,4\end{array}$ & $1-2$ & $\Pi$ & $\begin{array}{c}\text { ограниченного } \\
\text { пользования }\end{array}$ \\
\hline 16 & P. glauca «Daisy's White» & 1 & 2 & 2 & 2 & ДК & $\begin{array}{c}\text { В } 10 \text { лет: } \\
H-0,4 \\
D-0,3\end{array}$ & $1-2$ & $\Pi$ & $\begin{array}{c}\text { ограниченного } \\
\text { пользования }\end{array}$ \\
\hline 17 & P. glauca «Perfecta»» & 1 & 3 & 2 & 3 & Д & $\begin{array}{c}\text { В } 10 \text { лет: } \\
H-1 \\
D-0,6\end{array}$ & $2-3$ & МНП & частные сады \\
\hline 18 & P. pungens «Bialobok» & 1 & 2 & 2 & 1 & Д & $\begin{array}{c}\text { В } 15 \text { лет: } \\
H-1,5 \\
D-0,8\end{array}$ & $2-3$ & $\Pi$ & $\begin{array}{c}\text { ограниченного } \\
\text { пользования }\end{array}$ \\
\hline 19 & P. pungens «Glauca» & 1 & 1 & 1 & 1 & Д & $\begin{array}{c}\text { В 12лет: } \\
H-1,7 \\
D-0,9\end{array}$ & $4-5$ & $\mathrm{C \Pi}$ & $\begin{array}{c}\text { общего } \\
\text { пользования }\end{array}$ \\
\hline 20 & $\begin{array}{l}\text { P. pungens «Glauca } \\
\text { Globosa» }\end{array}$ & 1 & 1 & 1 & 1 & ДК & $\begin{array}{c}\text { В 12лет: } \\
H-0,4 \\
D-0,4\end{array}$ & $3-4$ & $\mathrm{C} \Pi$ & $\begin{array}{c}\text { общего } \\
\text { пользования }\end{array}$ \\
\hline 21 & P. omorica (Panc.) Purk & 1 & 2 & 2 & 1 & Д & $\begin{array}{c}\text { В 15лет: } \\
H-2,4\end{array}$ & $10-12$ & $\Pi$ & $\begin{array}{c}\text { ограниченного } \\
\text { пользования }\end{array}$ \\
\hline 22 & $\begin{array}{l}\text { Pinus mugo var. Pumilio } \\
\text { (Haenke) Zenari }\end{array}$ & 1 & 1 & 1 & 1 & $\mathrm{KC}$ & $\begin{array}{c}\text { В 15лет: } \\
H-1 \\
D-1,3\end{array}$ & $6-7$ & $\mathrm{C \Pi}$ & $\begin{array}{c}\text { общего } \\
\text { пользования }\end{array}$ \\
\hline 23 & $\begin{array}{l}\text { P. mugo var.mughus } \\
\text { (Scop.) Zenari) }\end{array}$ & 1 & 1 & 1 & 1 & $\mathrm{KC}$ & $\begin{array}{c}\text { В 13лет: } \\
H-1 \\
D-1,1 \\
\end{array}$ & $7-8$ & $\mathrm{C} \Pi$ & $\begin{array}{c}\text { общего } \\
\text { пользования }\end{array}$ \\
\hline 24 & $\begin{array}{l}\text { Thuja occidentalis «Bra- } \\
\text { bant » }\end{array}$ & 2 & 2 & 2 & 2 & Д & $\begin{array}{c}\text { В 13лет: } \\
H-1,7 \\
D-1\end{array}$ & 12 & МНП & частные сады \\
\hline 25 & T. occidentalis «Danica» & 1 & 1 & 1 & 1 & КШ & $\begin{array}{c}\text { В } 10 \text { лет: } \\
H-0,4 \\
D-0,4\end{array}$ & $2-3$ & $\mathrm{C \Pi}$ & $\begin{array}{c}\text { общего } \\
\text { пользования }\end{array}$ \\
\hline 26 & $\begin{array}{l}\text { T. occidentalis } \\
\text { «Holmstrup» }\end{array}$ & 1 & 2 & 2 & 2 & КП & $\begin{array}{c}\text { В } 10 \text { лет: } \\
H-0,8 \\
D-0,3\end{array}$ & 4 & МНП & частные сады \\
\hline 27 & T. occidentalis «Smaragd» & 1 & 1 & 1 & 2 & Д & $\begin{array}{c}\text { В } 10 \text { лет: } \\
H-1,5 \\
D-0,7\end{array}$ & 5 & $\Pi$ & $\begin{array}{c}\text { ограниченного } \\
\text { пользования }\end{array}$ \\
\hline
\end{tabular}

Примечания к таблице :

Морозоустойчивость: 1 - высокая или абсолютная, 2 - достаточно высокая, 3 - недостаточная, 4 - отсутствует.

Засухоустойчивость: 1 - высокая, 2 - менее высокая, 3 - средняя, 4 - низкая.

Газоустойчивость: 1 - высокая, 2 - средняя, 3 - низкая.

Устойчивость к солнечным ожогам: 1 - высокая, 2 - средняя, 3 - низкая.

Жизненная форма: Д - дерево, ДК - дерево карликовое, КР - кустарник раскидистый, КС - кустарник стелющийся, КП - кустарник прямостоячий, КШ - кустарник шаровидный.

Класс перспективности: СП - самые перспективные, П - перспективные, МНП - менее перспективные.

Даннье авторов.

\section{Заключение}

Анализируя результаты исследований, нужно отметить, что далеко не все изученные виды и культивары хвойных экзотов можно рекомендовать для массового озеленения городских пространств. К широкому и повсеместному применению во всех районах города, в том числе с повышенной антропогенной нагрузкой (объекты озеленения общего пользования), рекомендуются только те виды, которые легко переносят городские условия, устойчивы к промышленным поллютантам и не подвержены ранневесенним солнечным ожогам. К таким видам и формам по результатам наших 
исследований относятся: Abies concolor «Violacea», Juniperus communis «Green Carpet», J. horizontalis "Blue Chip», J. sabina "Giauca», J. sabina "Tamariscifolia», Picea pungens «Glauca», P. pungens «Glauca Globosa», Pinus mugo var. Pumilio (Haenke) Zenari, P. mugo var.mughus (Scop.) Zenari), Thuja occidentalis «Danica». Данные таксоны получили наивысшую интегральную оценку перспективности и были отнесены к классу «самые перспективные». Эти виды и культивары способны обогатить ассортимент городских зеленых насаждений и значительно усилить архитектурно-художественную привлекательность городов.

Такие виды и формы, как Abies concolor «Winter Gold», Juniperus horizontalis «Prince of Wales», J. media «Pfitzeriana», J. squamata "Blue Carpet», J. squamata "Blue Swede», J. virginiana «Blue Cloud», Picea abies «Nidiformis», P. glauca «Conica», P. glauca «Daisy's White», P. pungens «Bialobok», P. omorica (Panc.) Purk, Thuja occidentalis «Smaragd», получили во время исследования меньшее количество баллов интегральной оценки перспективности и отнесены к классу «перспективные». Данные виды и селекционные формы можно рекомендовать для более благоприятных мест: лесопарковых 30н, объектов озеленения ограниченного пользования (территорий различных учреждений, санаториев, малых садов, садов на крышах, декоративных групп у входов в офисы и торговые центры и т.д.). Такие растения нуждаются в укрытии от весеннего солнца и более тщательном уходе.

Виды и сорта с наименьшей устойчивостью к засухе, солнечным ожогам и чувствительные к городскому воздуху (Juniperus chinensis «Blue Alps», Picea abies «Acrocona», P. glauca «Perfecta», Thuja occidentalis «Brabant») получили во время исследования низкие интегральные оценки перспективности и отнесены к классу «менее перспективные». Данные виды и формы рекомендуется выращивать в частных садах на дачных и коттеджных участках. При этом необходимо отметить, что эти растения являются достаточно зимостойкими и прекрасно зимуют в условиях Братска, практически не повреждаясь морозами, но плохо переносят городской воздух, засуху и сильно повреждаются весенним солнцем, поэтому требуют особых условий и тщательного ухода.

Разработка районированного ассортимента хвойных пород для зеленого строительства городов с суровым климатом требует длительных и тщательных наблюдений и специальных исследований. Опыт частных питомников и коллекций древесных растений очень важен для разработки районированного ассортимента. Материалы нашего исследования показывают, что перспективы расширения и улучшения ассортимента древесных растений в Братске и других городов северных районов Иркутской области большие и перед работниками зеленого строительства открывается огромный фронт работы. Это же подтверждает и сравнение ассортимента зеленых насаждений городов северных территорий Иркутской области - Братска, Усть-Илимска, Усть-Кута, Бодайбо с такими городами, как Красноярск, Новосибирск, Томск, где сходные природно-климатические условия, но намного больший ассортимент городских насаждений.

\section{Список литературы / References}

1. Рунова Е.М., Гнаткович П.С., Золотухина Г.И. Оценка видового разнообразия древесных интродуцентов г. Братска // Системы. Методы. Технологии. 2015. № 3 (27). C. $149-156$

Runova E.M., Gnatkovich P.S., Zolotukhina G.I. Assessment of the species diversity of tree introduced species in the city of Bratsk // Sistemy. Metody. Tekhnologii. 2015. No. 3 (27). P. 149-156 (in Russian)

2. Рунова Е.М., Гнаткович П.С. Видовой состав зеленых насаждений общего пользования г. Братска // Системы. Методы. Технологии. 2013. № 2 (18). С. 156-159.

Runova E.M., Gnatkovich P.S. Species composition of green spaces for general use in the city of Bratsk // Sistemy. Metody. Tekhnologii. 2013. No. 2 (18). P. 156-159 (in Russian).

3. Бунькова Н.П., Залесов С.В., Платонов Е.П., Соловьева М.В. Перспективность использования можжевельника скального в озеленении города Екатеринбурга // Успехи современного естествознания. 2020. № 7. C. 7-12.

Bunkova N.P., Zalesov S.V., Platonov E.P., Solovyova M.V. Prospects for the use of rocky juniper in landscaping the city of Yekaterinburg // Uspekhi sovremennogo yestestvoznaniya. 2020. No. 7. P. 7-12 (in Russian).

4. Крекова Я.А. Оценка перспективности хвойных интродуцентов для озеленения и лесоразведения на территории Казахского мелкосопочника: автореф. дис. ... канд. сельхоз. наук. Екатеринбург, 2018. 24 с.

Krekova Ya.A. Assessment of the prospects of coniferous introduced species for landscaping and afforestation on the territory of the Kazakh Upland: avtoref. dis. ... kand. s.-kh. nauk. Yekaterinburg, 2018. 24 p. (in Russian).

5. Рунова Е.M., Гнаткович П.С. Перспективы внедрения интродуцентов частных садов в ассортимент зеленых насаждений города Братска // Лесотехнический журнал. 2014. T. 4. № 2 (14). C. 68-78.

Runova E.M., Gnatkovich P.S. Prospects for the introduction of introduced private gardens into the assortment of green spaces in the city of Bratsk // Lesotekhnicheskiy zhurnal. 2014. Vol. 4. No. 2 (14). P. 68-78 (in Russian).

6. Шестак К.В. Оценка адаптационной способности интродуцентов европейской и дальневосточной флор в дендрарии СибГТУ // Плодоводство, семеноводство, интродукция древесных растений: материалы VII Международной научной конференции. Красноярск: СибГТУ, 2004. C. 204-208.

Shestak K.V. Assessment of the adaptive ability of introduced species of the European and Far Eastern flora in the arboretum of the Siberian State Technical University // Plodovodstvo, semenovodstvo, introduktsiya drevesnykh rasteniy: 
materialy VII Mezhdunarodnoy nauchnoy konferentsii. Krasnoyarsk: SibSTU, 2004. P. 204-208 (in Russian).

7. Буторова О.Ф., Братилова Н.П., Глушкова Е.В. Интродукция растений североамериканской флоры в ботаническом саду им. Вс.М. Крутовского // Современные проблемы гуманитарных и естественных наук: материалы XXXII международной научно-практической конференции. В 2 ч. 2017. C. 39-44.

Butorova O.F., Bratilova N.P., Glushkova E.V. The introduction of plants of the North American flora in the Botanical Garden. Sun M. Krutovsky // Sovremennyye problemy gumanitarnykh i yestestvennykh nauk: materialy XXXIII mezhdunarodnoy nauchno-prakticheskoy konferentsii. V 2 ch. 2017 P. 39-44 (in Russian).

8. Кожевников А.П., Залесов С.В. Опыт создания коллекций плодовых и декоративных культур. Екатеринбург, 2018. 206 c

Kozhevnikov A.P., Zalesov S.V. Experience in creating collections of fruit and decorative crops. Yekaterinburg, 2018. 206 p. (in Russian).
9. Лапин П.И., Сиднева С.В. Оценка перспективности интродукции древесных растений по данным визуальных наблюдений // Опыт интродукции древесных растений. М.: Наука, 1973. С. 67-75.

Lapin P.I., Sidneva S.V. Assessment of the prospects for the introduction of woody plants according to visual observations // Opyt introduktsii drevesnykh rasteniy. M.: Nauka, 1973. P. 67-75 (in Russian).

10. Гусев А.В., Залесов С.В., Сарсекова Д.Н. Методика определения перспективности интродукции древесных растений // Социально-экономические и экологические проблемы лесного комплекса в рамках концепции 2020: материалы VII Междунар. научно-техн. конф. Екатеринбург: Урал. гос. лесотехн. ун-т, 2009. С. 272-275.

Gusev A.V., Zalesov S.V., Sarsekova D.N. Methods for determining the prospects for the introduction of woody plants // Sotsial'no-ekonomicheskiye i ekologicheskiye problemy lesnogo kompleksa v ramkakh kontseptsii 2020: materialy VII Mezhdunar. nauch.tekhn. konf. Yekaterinburg: Ural. gos. lesotekhn. un-t, 2009. P. 272-275 (in Russian) 